\title{
On mediating agents' moves and how they might affect patient- centredness in mediated medical consultations
}

\author{
Demi K. Krystallidou \\ University College Ghent / Ghent University
}

The present study aims to shed some light on indicators that might potentially challenge patient-centredness (as practised by self-professed patient-centred doctors) within a mediated medical encounter, and to contribute to the fields of linguistics, translation studies and medical communication. Selected instances of transcribed video recordings are analysed within the framework of Goffman's footing and participation roles, while transcribed audio recorded interviews with participants in the triad are taken into consideration as well. Both verbal and non-verbal cues (i.e., gaze) are taken into account. The data is drawn from a corpus of video-recorded mediated consultations in a urban hospital in Belgium. Hospital ethical approval and subjects' written informed consent have been obtained.

\section{The concept of patient-centredness}

The patient-centred approach is strongly advocated in medicine and is associated with positive outcomes in clinical practice such as patient satisfaction, higher rates of treatment adherence, patient empowerment and reduced health care costs (Hall, Roter, \& Katz, 1988; Little et al., 2001; O'Hair, O'Hair, Southward, \& Krayer, 1987; Roter, 1989; Roter, Hall, \& Katz, 1987; Smith et al., 1995; Stewart, 1984). However there is no actual consensus in the literature as to the exact meaning of patient-centredness (Hudon, Fortin, Haggerty, Lambert, \& Poitras, 2011). A review of the literature reveals, among other things, that there are different patientcentred approaches available (for an overview see Sarangi, 2007) and various instruments have been devised to measure patient-centredness in clinical encounters (e.g., Epstein et al., 2005; Mead \& Bower 2000).

Among the definitions of models of patient-centredness, the one developed by Epstein et al. (2005) focuses on the communicative dimension of patient-centredness, aiming at reaching the optimal delivery and receipt of healthcare through a mutually participatory doctor-patient relationship. For Epstein et al. (2005) patient-centred doctors aim at: eliciting and understanding their patients' perspectives, including their concerns, expectations, needs, feelings and ideas; understanding their patients within their unique psychosocial context; reaching a shared understanding of the problem and its treatment with their patients that corresponds to their patients' values; and helping patients to share power and responsibility by involving them in choices to the degree they wish. 
Although the above patient-centred communicative model focuses on the communication efforts initiated only by the doctor, all aspects of it pertain to the relationship between the doctor and the patient, within which patient-centredness can be implemented. In other words, in order for doctors to be able to practice patient-centredness as described by Epstein et al. (2005), the doctor-patient relationship must be such that patients trust their doctors, are willing to share more information with them and feel comfortable being involved in their treatment. (This is in line with Little et al., 2001; Mead \& Bower, 2000; Meeuwesen, Schaap, \& van der Staak, 1991; Stewart, 2001). It is important to note that seminal qualitative studies suggest that the doctor-patient relationship is subject to the image of active listening that doctors project to their patients, who, when they feel they have their doctors' genuine interest, begin to place trust in the relationship, feel better and become more active and engaged partners in their care (Stewart, 2005).

To assess their doctors' interest in them patients employ certain criteria, one of which is the doctors' patient-oriented gaze. In western cultures establishing and maintaining moderate to high levels of eye contact with a discourse participant conveys interest in the discourse participant in question. On the contrary, avoiding or maintaining low eye contact while talking to a discourse participant can prevent the rapport building because it conveys lack of interest, detachment and dislike (Heintzman, Leathers, Parrott, \& Caims, 1993). In the context of medical consultations it has been shown that the duration of a doctor's gaze at a patient influences the latter's active engagement in his or her care and the duration of his or her speaking time (Bensing, Kerssens, \& van der Pasch, 1995).

Apart from the relatively high rates of doctor-patient eye contact, the doctor's and the patient's ability to communicate with each other is required in order for the doctor-patient relationship to develop and so as to permit the successful implementation of patient-centred communication. However, rapid increase in immigration has resulted in global demographic shifts to such an extent that patients do not always share a common language with their doctors and are sometimes unable to communicate with them. Therefore alongside ad hoc interpreters (who are untrained and unofficial), professional interpreters and cultural mediators (henceforth: Mediating Agents, $\mathrm{MAs}^{1}$ ) are being employed in healthcare settings in order to enable communication to take place between native healthcare providers and ethnic minority patients in the presence of language barriers.

\section{Mediated doctor-patient communication within the framework of patient-centredness as presented in the literature}

Although the practice of mediated doctor-patient communication has been increasingly receiving scholars' attention, most studies focus either on the 
MAs' role(s) (Davidson, 2001; Meeuwesen, Twilt, ten Thije, \& Harmsen, 2010; Wadensjö, 1998;) or on doctors' perceptions of MAs (Fatahi, Hellström, Skott, \& Mattsson, 2008; Rosenberg, Leanza, \& Seller, 2007). What is also addressed is the difficulties that are likely to emerge from the transformation of typically dyadic (doctor-patient) monolingual medical consultations into triadic ones involving an interpreter (doctor-interpreterpatient) (Bischoff, Tonnerre, Loutan, \& Stalder, 1999; Diamond \& Jacobs, 2010; Diamond, Schenker, Curry, Bradley \& Fernandez, 2009; DysartGale, 2005;) where a shift in the dynamics of doctor-patient communication (i.e., interpreters taking over the control of the conversational organization of the consultation and of the turn distribution among participants) has been acknowledged (Briskina, 1996; Kaufert \& Putsch, 1997).

To date there are not many studies investigating mediated doctorpatient communication in relation to the concept of patient-centredness. The available studies on mediated medical communication that touch upon aspects of patient-centredness suggest that the MAs' presence does change crucial aspects of the nature of the doctor-patient interaction. More precisely, doctors find it difficult to develop a relationship with their patients and understand their life-world (Rosenberg et al., 2007); they tend to establish and maintain eye-contact more with the MAs than with their patients (Baker, Hayes, \& Puebla Fortier, 1998); they feel at times excluded from the patient-(professional) interpreter interaction (Rosenberg et al., 2007); they perceive patients as low-compliant and not much engaged (Aranguri, Davidson, \& Ramirez, 2006); they do not engage in social interaction with their patients (Aranguri et al., 2006; Fatahi et al., 2008). Patients, on the other hand, tend to ask fewer questions of their doctors (Aranguri et al., 2006) and perceive them as less friendly, less respectful and less concerned for them as a person when they are assisted by mediating agents (Baker et al., 1998).

What becomes apparent in the literature is a shift from the (until recently unquestioned) assumption of the MAs' facilitating impact to the assumption that the impact of the presence of an MA might actually be disturbing and even complicate the doctor-patient communication (Fatahi et al., 2008; Hadziabdic, Heikkilä, Albin, \& Hjelm, 2009; Weiss \& Stuker, 1999;). Yet, few studies explicitly relate the MAs' impact to the doctorpatient relationship and to patient-centredness. A notable exception is the study by Baraldi and Gavioli (2008) where there is reference to the way MAs might affect patient-centred communication. More specifically, Baraldi and Gavioli (2008) suggest among other things that patientcentredness might be hampered by the presence of mediators. However, they take only verbal cues into account and fail to provide evidence of how the combination of mediators' verbal and non-verbal cues might have an impact on doctor-patient communication.

In this paper I will demonstrate how MAs' moves in the triad might affect communication and the doctor-patient relationship in mediated 
consultations. In order to define the term "move" I rely both on Goffman ( as presented in Manning, 1992, pp. 168-169) and on Bellack, Kliebard, Hyman and Smith as presented in Coutlhard (1997, p. 97) respectively without, however, adopting entirely either of the available definitions. ${ }^{2}$ Instead I borrow elements that seem to be common in both models. In this light by the term "move" in this paper I mean a unit of discourse. A move is to be found in a participant's utterance and might serve specific purposes such as to set the context for subsequent participant behaviour, to elicit verbal and/or non-verbal participants' response, or to respond or to react to participants' preceding moves. By "triad" I mean the typical set-up of mediated consultations including the doctor, the MA and the patient.

More specifically in this paper I will take both verbal and non-verbal cues (i.e., gaze) into account and will focus on the MA's moves when translating the doctor's utterances made to the patient and vice versa. Both the doctor's and the patient's moves as a response to those of the MA will be discussed as well. The stage of the doctor-patient communication where the doctor reaches a shared understanding with the patient and shares power and responsibility with him or her requires further research that would exceed the scope of this paper. The analysis of participants' moves is enhanced by the presentation of participants' views as expressed during the interview sessions that I held with them.

The investigation of the MAs' moves in the triad and their impact on the doctor-patient relationship in the framework of patient-centredness requires the parallel observation of the moves of the other participants (the doctor and the patient) as well. In order to do so I will draw on Goffman's (1981) "footing" and "participation framework", two conceptual tools that provide the means for parallel participant observation in the course of their interaction with each other.

\section{Footing and participation framework}

For Goffman (1981), "when a word is spoken, all those who happen to be in perceptual range of the event will have some sort of participation status relative to it" (p 3). What comes next is that the participants will draw on their own understanding of how they and the others are involved in this utterance and they will interact either by speaking or listening. The participants' alignment to this utterance, either as a speaker or a listener, is defined by Goffman (1981) as "footing" (p. 128). Goffman (1981) adds that "a change in footing implies a change in the alignment we take up to ourselves and the others present as expressed in the way we manage the production or reception of an utterance" (p. 128). The concept of footing has already been adopted by a number of scholars in the field of translation studies (Merlini \& Favaron, 2005) but it is Wadensjö (1998) who develops it further to account for the interpreter's roles. However, because of the lack 
of a consistent use of the term "role" in the translation studies and biomedical literature, I will avoid referring to MAs' roles in a generic and perhaps even arbitrary manner and instead I will adhere to the term "role" as it is used in Goffman's participation framework, where he distinguishes among production and reception roles, which discourse participants take on themselves or are assigned by the other interlocutors.

Among the roles in Goffman's production format the role of the "author" is attributed to the participant who "has selected the sentiments that are being expressed and the words in which they are encoded" (Goffman, 1981, p. 144); in other words, the "author" is the participant who generates the words. The role of the "principal" is allocated to the participant "whose position is established by the words that are spoken, someone whose beliefs have been told, someone who is committed to what the words say" (Goffman, 1981, p.144). Levinson (1988), drawing on Goffman, defines the role of the "principal" as "the party to whose position the words attest" (p. 169). In other words, the "principal" is the participant "held responsible for the position attested to by the meaning of what was spoken" (Manning, 1992, p. 171). The participant who is "active in the role of the utterance production" (Goffman, 1981, p. 144), or in other words, the participant who speaks the words, occupies for Goffman the role of the "animator". The words spoken by the "animator" have not been created by $\mathrm{him} /$ her; the "animator" is not held responsible for the meaning expressed by means of the words he or she speaks. It should perhaps be noted in passing that the role of the "animator" resembles the interpreter's function as described in the "conduit metaphor" inspired by Reddy's (1979) "conduit model" of communication, in which the interpreter is the language convertor, the channel that enables communication between interlocutors who do not share a common language. The interpreter in the role of the "animator" converts and speaks the words produced by the interlocutors, who apart from the production of the words, are also held responsible for the meaning expressed by their words.

Among the hearers of the speaker's utterance Goffman makes a distinction among "ratified" and "unratified" participants. According to Goffman (2005, p. 34) the ratification process is reciprocal among participants who, once they are ratified, are officially part of the encounter and are expected sooner or later to assume a speaking role. The participant to whom "the speaker addresses his visual attention" and who, incidentally, is expected "to turn over to the speaker role" is a ratified "addressed" participant (Goffman, 1981, pp. 132-133). The rest of the "official hearers" of the speaker's utterance, who may or may not be listening, are the ratified "unaddressed" participants. Among the non-official hearers there might be participants who have "purposely engineered" their listening to the speaker's utterance (eavesdroppers) and participants who "unintentionally and inadvertently" hear the speaker's utterance (Goffman, 1981, pp. 131132). 
Both types of role, namely production and reception roles, are subject to change. This means that they are not static and that recipients of an utterance might assume a speaking role, and vice versa. The shift from the role of a recipient to that of a speaker (e.g. from an addressed recipient to an author/principal) is subject to the participants' ratification by the speaker and the other participants. The recipient of an utterance to whom the "author" addresses his/her attention-by means of gaze or words-is expected to assume a speaking role. (For a more detailed account see Goffman, 1981, pp. 132-133; Manning 1992, p. 170.)

Although Goffman (1981) refers to interaction among multiple participants and problematizes the notion of its dyadic form as its fundamental unit, he establishes his participation framework with monolingual interaction in mind. When applied to cross-linguistic interaction-here, mediated doctor-patient communication-a significant limitation in Goffman's model can be noted: although Goffman (1981) takes gaze into account as an essential part of the ratification process, he does not include cases where the speaker ratifies two different participants at the same time - one verbally and one through gaze. Because the above ratification pattern has been identified multiple times in my corpus, a terminological distinction is necessary to capture the impact of the ratification process. Therefore I will distinguish between "ratified verbally addressed" and "ratified visually addressed" participants. When participants are both verbally and visually addressed, I will consider them as a "fully ratified participant". The participants who are only either verbally or visually addressed I will consider as "partially ratified".

Another issue that might raise concerns in mediated communication is the meaning of participant ratification. For Goffman (2005) participant ratification is reciprocal and is associated with participants' involvement in the communicative event. However, it is not clear whether limitations (caused, for example, by the language barrier) placed on participants' performance are taken into account when defining the degree of their selfinitiated involvement and thus the extent of their ratification. Perhaps within the context of mediated consultations, the term should refer to the participants' presence as a sine qua non in order for the mediated consultation to be held.

\section{Data and methodology}

For the analysis below I present excerpts of transcribed mediated consultations and interviews with doctors and mediating agents. The data analysed below form part of a corpus of 19 transcribed video-recorded mediated consultations and 27 audio-recorded interviews with doctors $(n=17)$ and MAs $(n=10)$, which I collected for my $\mathrm{PhD}$ research. The interviews were conducted by me in Dutch. All data were collected by me 
at an urban hospital in Flanders, Belgium between March 2010 and May 2011. The study has been approved by the hospital ethics committee and participants' written informed consent was obtained prior to their inclusion in the study. The transcription and translation into Dutch of all recorded material was conducted by (professional) trained translators and revised by native speakers with training in the field of translation studies. The translation into English is mine.

For the analysis of the corpus, as described above, I used directed content analysis (Hsieh \& Shannon, 2005). This means that I used existing theory and research (e.g. on mediated doctor-patient communication) as a guide for the development of codes during the analysis of the data. For the coding process I relied on Graneheim and Lundman's (2004) model. In the corpus of transcribed consultations and interviews I identified "meaning units", which I turned into "condensed meaning units" (first with a description close to the text of the selected instance; later on with an interpretation of the underlying meaning of the first condensed meaning unit). The interpretation of the underlying meaning lead to "sub-themes", which were grouped under "themes". (For a more detailed account see Graneheim \& Lundman, 2004.)

The excerpts from the mediated consultations, as well as the examples from the interviews presented in this paper have been selected at random among meaning units that were attributed to the same themes in the course of the analysis process. For this paper I selected themes that in my view could provide insights into the concept of patient-centredness in mediated consultations. The themes that seemed to be somehow related to the communicative aspect of patient-centredness as described above by Epstein et al. (2005) were "dual ratification process", "shifts between a Weand You identity" and "negotiation of roles by MAs", to mention but a few.

\section{Taking a closer look at participants' moves}

Excerpt 1 provides evidence for a dual yet distinct ratification process by the doctor. (Transcription conventions are provided in the endnotes sections. ${ }^{3}$ )

(1) $1 \mathrm{D} 4 \mathrm{P}$ : $\quad$ heeft ze nog kindjes of niet?

$=$ [does she have any more children or not?]

2 MA ४Р: есть у вас детей ещё или нет?

$=[$ do you have any other children or not?]

3 Р МА: Да (.) две довочки 


\section{MA 4D: twee meisjes \\ $=[$ two girls $]$}

$=[$ yes $($.$) two girls ]$

In turn 1 the doctor verbally addresses the MA while looking at the patient. The doctor, who has assumed the role of the author and principal, assigns the role of the ratified verbally addressed recipient of their question (turn1) to the MA who is expected by the doctor to assume the role of the animator and render the patient's response to the doctor. This is in line with the doctor's expectations of MAs as emerged from the interviews with them (see Example 1 below).

Example 1: (...)wel ik denk dat een tolk of een bemiddelaar de informatie die gegeven wordt door de patiënt of de arts op een correcte manier en volledig moet vertalen zonder interpretatie te geven aan wat één van beide partijen gezegd heeft.

$=$ [well I think that an interpreter or a mediator must translate the information given by the patient or the doctor accurately and completely without adding his/her own interpretation of what was said by one of the two parties.] (Doctor X)

However, at the same time the doctor directs his/her gaze to the patient, turning him/her into a ratified verbally unaddressed yet visually addressed participant.

Unlike the doctor, the MA addresses the patient both verbally and visually (turn 2), thus turning him/her into a fully ratified addressed recipient. What is interesting to note is the change in footing in turn 2 . The MA assumes a speaking role that does not correspond entirely to the role of the animator, contrary to the doctor's expectations. Instead, the interpreter slightly re-scripts the doctor's utterance by changing the personal pronoun "she" into "you". Strictly speaking, such interventions by MAs turn them partially into authors and principals, since the words they speak are partially enhanced by those they generate (here: "you"). They therefore assume partial responsibility for the position produced by the meaning of what was just spoken (Manning, 1992, p. 171). It should be noted here that the vast majority of the doctors participating in the study reported during the interview sessions that they expected MAs to act as "translation machines" of their own and their patient's utterances "without changing anything in the message". Obviously doctors and linguists' views on the term "message" might differ significantly but what most doctors in this study expected of MAs was a neutral position in the doctor-patient relationship and the communication that it required. Instead, the MA in excerpt 1 opts for a shift in the pronouns and replaces the 3rd person pronoun ("she", turn1) by the 2 nd person pronoun ("you", turn 2). By doing so, the MA 
rejects the role of the author / principal the doctor assumed in turn 1 and the MA re-scripts the doctor's lines, assuming the role of the author him/herself to a certain extent. A similar case is to be found in excerpt 2, where the MA changes the "lady" into "our patient" (excerpt 2, turn 1).

(2) 1 D 4MA: ja (.) dus (.) wat (.) kan ik (.) voor mevrouw doen of $($.$) voor wat komt ze naar hier$ $=[$ yes (.) so (.) what (.) can I (.) do for the lady or (.) why is she here]

2 MA 4P: hastamız için ne yapabilirim (.) buraya niye geldi $=[$ what can I do for our patient (.) why is she here

$3^{4}$ P 4MA: ben (.) midem şişiyor (.) yemek yedim mi sancılaşma (.) kasıklarım sancıyor (.) buraya iniyor. (.) diare oldum (.2) dişarı atıyom. (.2) ne yersem ekşiyor (.) öyle işte ((yerini eli ile gösteriyor))

$=[$ my stomach gets swollen (.) when I eat I get cramps and I feel pain in my groin (.) the pain goes to the lower part (.) I have diarrhoea (.2) everything I eat turns sour (.2) this is more or less here ((the patients points to her body))]

4 MA 4Floor: ik heb e: (.) zwelling in mijn maag (.) e::: zeker na het eten pijngevoel onder andere (.) toch pijngevoel in mijn ( ) altijd hier en ik heb wel $=[$ I feel e: (.) my stomach swollen (.) e::: certainly after eating feeling of pain among others (.) pain in my ( ) always here and I also have]

5 MA 4 D: last van diarree

$=$ diarrhoea $]$

6 D MA: en sinds wanneer heeft mevrouw klachten daarvan?

$=$ and how long has the lady been having these symptoms?]

7 MA 4P: ne kadar zamandır ağrınız var?

$=$ [how long have you been suffering feeling pain?]

In excerpt 2 (turn 1), the doctor acknowledges the MA's presence and ratifies him/her fully (verbal and visual address), expecting him/her to assume the role of the animator. Although the doctor's expectations as to 
the MA's role are not entirely clear in turn 1, the doctor's views in the interview confirm the above assumption. "Voor mij is een tolk iemand die mijn uitleg overbrengt in de taal van de patiënt; dat is voor mij de functie van de tolk" $=[$ To me an interpreter is someone who transfers my explanation into the patient's language; that to me is the interpreter's function] (Doctor Y). The MA (turn 2), on the other hand, fully aware of the code of conduct he or she abides by (as was reported during the interview session), changes the footing by trying to minimize the impact of his/her presence and appear more like a "translation machine" or a "sounding box" in Goffman's terms (1981, p. 144). "Ik ben gewoon een tussenpersoon in de consultatie" $=[\mathrm{I}$ am just an intermediary person in the consultation] was the MA's response when he or she was asked to define his/her tasks as MA. The MA (2) ratifies the patient by addressing them both verbally and visually.

It is interesting to note the shift in footing in turns 1 and 2. The doctor's utterance, "for the lady" (turn 1), becomes "for our patient" (turn 2 ) in the MA's utterance. This change in footing reveals the construction of a We-identity (Baraldi \& Gavioli, 2008) that the MA wants, that the doctor shares with the patient and not with the MA. In other words, the MA rejects the doctor's attempt to make the MA's presence "visible" by acknowledging his/her as someone with whom the doctor shares some common ground (e.g. familiarity with mediated consultations, professional status, same workplace). Instead, the MA tries to bring the doctor and the patient closer to each other by rejecting the doctor's "invitation" to join his/her We-identity and by changing his/her footing. Contrary to my expectations, none of the MAs interviewed reported being familiar with the concept of patient-centredness. Therefore, the MA's move in reconstructing the doctor's We-identity and wanting to include the patient in it originates most likely from the MA's training and the code of conduct that the MA abides by.

In turn 3 the patient assumes the role of the author and principal, and turns the MA into a ratified, both visually and verbally addressed participant, while excluding the doctor, who is now a ratified unaddressed participant.

In turn 4 the MA maintains the 1st person pronoun and takes on the role of the animator, while re-scripting somehow at the same time the doctor's lines by omitting certain elements (e.g. cramps, food turning sour in the patient's stomach, and so forth) and thus assuming the author's roleat least to some extent. It is noteworthy that the MA in turn 4 avoids visually addressing either of the participants by looking instead at the floor. Only in turn 5 does the MA turn his/her gaze to the doctor.

(3) 1 D 4P:één keer zwanger geweest ook? $=[$ also have you been pregnant once?] 
$2 \mathrm{MA}<\mathrm{P}$ : bir defa mı hamile kaldın?

$=$ [have you been pregnant only once?]

3 P 4MA: hı (.2) [onda da bu şeyler olmadı

$=$ [yes] (.2) during the pregnancy I did not have these things]

$4 \mathrm{D} 4 \mathrm{PC}$ : [uw zoon is gezond?

$=[$ is your son healthy?]

5 MA ४P: çocuk sağliklı mı? $=$ [is your child healthy?]

6 P 4 MA: h1

$=[$ yes $]$

7 MA $4 \mathrm{D}$ : ja hij is gezond

$=$ [ yes he is healthy]

$8 \mathrm{D}<\mathrm{P}: \quad$ rookt $\mathrm{u}$ ?

$=$ [do you smoke?]

$9^{5} \mathrm{MA} \triangleleft \mathrm{P}$ : sigara içiyor musun?

$=$ [do you smoke?]

What is interesting to note in turn 3 is the patient taking on the role of the author and the principal of their utterance, who before completing it, is being interrupted by the doctor who assumes the role of the author and principal as well (turn 4). The MA aligns with the doctor and becomes the animator of the doctor's utterance (turn 5: "is your child healthy?") and not of the patient's utterance (3: "during the pregnancy I did not have these things"). The patient's utterance (turn 3) is attended neither by the MA nor by the doctor, who as soon as he or she receives a response to his/her next their utterance, proceeds to the next question (turn 8). In turn 6 the patient addresses the MA verbally and visually, leaving the doctor unaddressed. In turns 7 and 9 the MA assumes the role of animator and author to some extent.

\section{Participants' impact on doctor-patient communication and relationship}

From the excerpts above it emerges that all parties in the triad are likely to influence the doctor-patient relationship. Table 1 summarizes the forms that this influence can take. 
Table 1: Participants' impact on the doctor-patient communication

\begin{tabular}{|c|c|c|}
\hline Participant & Way(s) of affecting doctor-patient communication & Excerpt \\
\hline \multirow[t]{2}{*}{ Doctor } & a. Dual yet distinct participant ratification & 1 \\
\hline & b. Orientation toward a We-identity with the MA & 2 \\
\hline Patient & $\begin{array}{l}\text { Visual / verbal address of one participant (mostly the } \\
\text { MA) and exclusion of the other (mostly the doctor) }\end{array}$ & 1 \\
\hline \multirow[t]{4}{*}{ MA } & $\begin{array}{l}\text { a. Becomes the main focus of other participants' } \\
\text { visual or verbal address (macro level) }\end{array}$ & $1,2,3$ \\
\hline & b. "Selective" animator (micro level) & 3 \\
\hline & c. "Selective" author (micro level) & $1,2,3$ \\
\hline & $\begin{array}{l}\text { d. Focus shifts away from the doctor's We-identity } \\
\text { (doctor-MA) / construction of a You-identity (doctor- } \\
\text { patient) }\end{array}$ & 2 \\
\hline
\end{tabular}

\subsection{The doctors' impact}

The doctors in all excerpts above reported during the interview sessions that they were aware of the concept of patient-centredness and the benefits associated with it. All of them stated that they had tried to follow a patientcentred approach towards their patients (including ethnic minority patients) but at the same time they pointed out that in practice patient-centredness was usually compromised by time constraints that applied to their daily practice.

Besides their familiarity with the concept of patient-centredness, doctors might affect the doctor-patient relationship in two distinct ways: through the ratification of participants (incorporating the distinction introduced above) and through their orientation towards a We-identity that includes themselves and the MA. Doctors might engage simultaneously in the dual ratification process and this might result in their projected interest not being focused on the patient (as defined in patient-centred models) but moving instead to the MA. By doing so, on a macro level the doctor aims at understanding the patient in his/her own psychosocial context by eliciting responses that might enhance the doctor's insight into the patient's problem, leading ideally to a shared understanding between the doctor and the patient and to the fostering of their relationship, which is essential in the framework of patient-centredness. A closer look, however, might suggest that at a micro level the doctor's moves increase the distance between the doctor and the patient. The increase in distance in the doctor-patient relationship occurs when the doctor fully ratifies the MA as an addressed participant and by doing so excludes the patient. This is so because the MA's dual ratification by the doctor turns the patient into a ratified unaddressed participant. The more often this specific participation 
framework occurs, the more distance is added to the doctor-patient relationship.

The doctors in the above excerpts are familiar with the MAs as they have already worked together several times. During the interview sessions some of the doctors stated that although they knew that the MAs' task was mainly focused on interpreting (for interpreters it was limited solely to interpreting), they sometimes expected them to elicit as much information as possible from the patient or even provide the doctor with any background information they might have with regard to the patient. This might make doctors expect MAs to align themselves with them and be part of the Weidentity doctors construct for them and the MAs. This is more likely to happen when the MAs are staff members of the hospital.

Once again at a macro level the doctors' orientation toward a Weidentity with MAs might aim at the elicitation of information but at the same time, at a micro level, it increases the distance between the doctor and the patient and makes their relationship less direct, thus affecting patientcentredness in the consultation.

\subsection{The patients' impact}

The language barrier does not allow ethnic minority patients to have direct access to their doctors' utterances and therefore they need to rely exclusively on the MAs' renditions. Because the MA is the only participant in the triad whose utterances patients understand, patients tend to establish more eye contact with them than with the doctor. Unlike self-professed patient-centred doctors, patients in my corpus are less likely to engage in dual and distinct ratification of participants. Instead, they mostly look at the MA every time they address them verbally. When they do so, they somehow exclude the doctor who is then attributed the role of the ratified unaddressed participant. Doctors' exclusion and MAs' inclusion by patients and the patients' higher eye-contact rate with MAs hamper the construction of a doctor-patient relationship as intended in the patient-centred context.

\subsection{The MAs' impact}

In the above excerpts it was shown that MAs might affect the impact on the doctor-patient-relationship in two ways. At a macro level, their presence and professional status yield expectations among the other participants who see in the MA a participant who is able to understand and respond fully to their utterances in their own language. The MAs' presence results in doctors and patients establishing more eye contact with them than with each other. This shift in participants' visual focus onto MAs is likely to impede the rapport building between the doctor and the patient, and may convey 
detachment, lack of interest or even dislike between participants (Heintzman et al., 1993), ultimately affecting the doctor-patient relationship.

However, MAs are also likely to engage in self-initiated moves and to act as "selective" animators, meaning that when they align with one participant, they might opt to act as the animator of that participant and to ignore the other participant's utterances, which eventually might be left unattended to. This results in certain information not reaching a particular participant (mostly the doctor), who might then be unable to understand the patient fully in his/her unique psychosocial context. Should this be the case, one of the basic aspects of the patient-centred model as defined by Epstein et al. (2005, p. 1517) might be left unattended.

Alternatively, MAs might take on the role of the "selective" author by re-scripting participants' lines, mostly through the omission of certain information. As in the case of the "selective" animator, MAs, by acting as "selective" authors, might prevent participants from gaining access to specific information released by another participant and consequently their mutual understanding might be impeded in the framework of patientcentredness.

As shown above another self-initiated move MAs engage in is the rejection of the doctors' We-identity (meant to encompass doctors and MAs) and the construction of a new You-identity meant to be limited to doctors and patients excluding MAs. When doing so, MAs draw on their training or the code of conduct they abide by whereby the notion of the MAs' "invisibility" remains central. Through shifts in footing, MAs often aim at re-shifting the focus onto either the doctor or the patient, when they feel that their normative role as stipulated in their code of conduct has been challenged. In this case the MAs' moves aim at decreasing the distance between doctors and patients, adhering to the interpreter's "invisibility" as promoted by the MAs' code of conduct. In doing so, MAs unwittingly promote the doctors' and patients' relationship in the context of patientcentredness.

\section{Summary of findings and limitations}

Among other things, it has been shown that MAs may both facilitate and hamper doctor-patient communication through their moves. The presence of a third participant, the MA, does affect the interaction dynamics in doctor-patient communication and might have a negative impact on the doctor-patient relationship through participants being excluded during the process of their ratification. I would hypothesize that for patientcentredness to be implemented in mediated consultations and for participants to stop being excluded during the process of their ratification, two prerequisites must be met: doctors should be patient-centred and $M A$ - 
minded, and MAs should be participant-centred and impact-minded. That means that doctors, on the one hand, apart from being patient-centred, should also be aware of the complexities inherent in mediated interaction. On the other hand, MAs should become familiar with the concept of patient-centredness and with their own impact on it. In order to investigate the above hypothesis extensive research into doctors' and MAs' perceptions of patient-centredness, as well as their training, is required.

Although the excerpts of the video-recorded mediated consultations and the views expressed by participants are not representative for the practice of mediated consultation as a whole, they do provide evidence for possible ways of affecting the doctor-patient communication. However, at a later stage the verification of the above findings should be attemptedincluding patients' views as expressed during interviews - in order to improve the validity of the findings presented in this paper.

\section{References}

Aranguri, C., Davidson, B., \& Ramirez, R. (2006). Patterns of communication through interpreters: A detailed sociolinguistic analysis. Journal of General Internal Medicine, 21(6), 623-629.

Baker, D. W., Hayes, R., \& Puebla Fortier, J. (1998). Interpreter use and satisfaction with interpersonal aspects of care for Spanish-speaking patients. Medical Care, $36(10), 1461-1470$.

Baraldi, C., \& Gavioli, L. (2008). Cultural presuppositions and re-contextualization of medical systems in interpreter-mediated interactions. Curare: Zeitschrift für Ethnomedizin und Transkulturelle Psychiatrie, 31(2-3), 193-204.

Bensing, J. M., Kerssens, J. J., \& van der Pasch, M. (1995). Patient-directed gaze as a tool for discovering and handling psychosocial problems in general practice. Journal of Nonverbal Behavior, 19(4), 223-243.

Bischoff, A., Tonnerre, C., Loutan, L., \& Stalder, H. (1999). Language difficulties in an outpatient clinic in Switzerland. Sozial- und Präventivmedizin, 44, 283-287.

Briskina, G. (1996, March). Understanding the interpreter's role: An analysis of interpreter-mediated doctor patient communication. Paper presented at the annual meeting of the American Association for Applied Linguistics, Chicago, Il, 23-26 March 1996. Retrieved 13.12.2011 from http://eric.ed.gov/ERICDocs/ data/ericdocs2sq1/content_storage_01/0000019b/80/14/ab/50.pdf (accessed 13 December 2011).

Coulthard, M. (1977). An introduction to discourse analysis. London: Longman.

Davidson, B. (2001). Questions in cross-linguistic medical encounters: The role of the hospital interpreter. Anthropological Quarterly, 74(4), 170-178.

Diamond, L. C., Schenker, Y., Curry, L., Bradley, E. H., \& Fernandez, A. (2009). Getting by: Underuse of interpreters by resident physicians. Journal of General Internal Medicine, 24(2), 256-262. 
Diamond, L. C., \& Jacobs, E. A. (2010). Let's not contribute to disparities: The best methods for teaching clinicians how to overcome language barriers to health care. Journal of General Internal Medicine, 25(2), 189-193.

Dysart-Gale, D. (2005). Communication models, professionalization, and the work of medical interpreters. Health Communication, 17(1), 91-103.

Epstein, R. M., Franks, P., Fiscella, K., Shields, C. G., Meldrum, S. C., Kravittz, R. L., \& Duberstein, P. R. (2005). Measuring patient-centered communication in patient-physician consultations: Theoretical and practical issues. Social Science \& Medicine, 61(7), 1516-1528.

Fatahi, N., Hellström, M., Skott, C., \& Mattsson, B. (2008). General practitioners' views on consultations with interpreters: A triad situation with complex issues. Scandinavian Journal of Primary Health Care, 26, 40-45.

Goffman, E. (1981). Forms of talk. Oxford: Basil Blackwell.

Goffman, E. (2005). Interaction ritual: Essays in face-to-face behavior. New Brunswick, NJ: Transaction.

Graneheim, U. H., \& Lundman, B. (2004). Qualitative content analysis in nursing research: Concepts, procedures and measures to achieve trustworthiness. Nurse Education Today, 24, 105-112.

Hadziabdic, E., Heikkilä, K., Albin, B., \& Hjelm, K. (2009). Migrants' perceptions of using interpreters in health care. International Nursing Review, 56, 461-469.

Hall, J. A., Roter, D. L., \& Katz, N. R. (1988). Meta-analysis of correlates of provider behavior in medical encounters. Medical Care, 26, 657-675.

Heintzman, M., Leathers, D. G, Parrott, R. L., \& Caims, I. (1993). Nonverbal rapportbuilding behaviours' effect on perceptions of a supervisor. Management Communication Quarterly, 7(2), 181-208.

Hsieh, H. F., \& Shannon, S. E. (2005). Three approaches to qualitative content analysis. Qualitative Health Research, 15(9), 1277-1288.

Hudon, C., Fortin, M., Haggerty, J., Lambert, M., \& Poitras, M. E. (2011). Measuring patients' perceptions of patient-centred care: A systematic review of tools for family medicine. Annals of Family Medicine, 9(2), 155-164.

Kaufert, M. J., \& Putsch, W. R. (1997). Communication through interpreters in healthcare: Ethical dilemmas arising from differences in class, culture, language and power. The Journal of Clinical Ethics, 8(1), 71-87.

Levinson, S. C. (1988). Putting linguistics on a proper footing: Explorations in Goffman's concepts of participation. In P. Drew \& A. Wooton (Eds.), Erving Goffman: Exploring the interaction order (pp. 161-227). Boston: Northeaster University Press.

Little, P., Everitt, H., Williamson, I., Warner, G., Moore, M., Gould, C., Ferrier, K., \& Payne, S. (2001). Observational study of effect of patient centredness and positive approach on outcomes of general practice consultations. British Medical Journal, 323(7318), 908-911.

Manning, P. (1992). Erving Goffman and modern sociology. Cambridge: Polity.

Mead, N., \& Bower, P. (2000). Patient-centredness: A conceptual framework and review of the empirical literature. Social Science \& Medicine, 51, 1087-1110. 
Meeuwesen, L., Schaap, C., \& van der Staak, C. (1991). Verbal analysis of doctorpatient communication. Social Science \& Medicine, 32(10), 1143-1150.

Meeuwesen, L., Twilt, S., ten Thije, J. D., \& Harmsen, H. (2010). "Ne diyor?" (What does she say?): Informal interpreting in general practice. Patient Education and Counseling, 81, 198-203.

Merlini, R., \& Favaron, R. (2005). Examining the "voice of interpreting" in speech pathology. Interpreting, 7(2), 263-302.

O'Hair, D., O’Hair, M. J., Southward, G. M., \& Krayer, K. J. (1987). Physician communication and patient compliance. The Journal of Compliance in Health Care. 2, 125-129.

Reddy, M. (1979). The conduit metaphor: A case of frame conflict in our language about language. In A. Ortony (Ed.), Metaphor and thought (pp. 284-324). Cambridge: Cambridge University Press.

Rosenberg, E., Leanza, Y., \& Seller, R. (2007). Doctor-patient communication in primary care with an interpreter: Physician perceptions of professional and family interpreters. Patient Education \& Counseling, 67, 286-292.

Roter, D. L., Hall, J. A,, \& Katz, N. R. (1987). Relations between physicians' behaviors and analogue patients' satisfaction, recall, and impressions. Medical Care, 25, 437-451.

Roter, D. (1989). Which facets of communication have strong effects on outcome: A meta-analysis. In M. Stewart \& D. Roter (Eds.), Communicating with medical patients (pp. 183-196). London: Sage.

Sarangi, S. (2007). Other-orientation in patient-centred healthcare communication: Unveiled ideology or discoursal ecology? In G. Garzone \& S. Sarangi (Eds.), Discourse, ideology and ethics in specialised communication (pp. 39-71). Bern: Peter Lang.

Silverman, D. (1993). Interpreting qualitative data: Methods for analysing talk, text and interaction. London: Sage.

Smith, R. C., Lyles, J. S., Mettler, J. A, Marshall, A. A., Van Egeren, L. F., Stoffelmayr, B. E., Osborn, G. G., \& Shebroe, V. (1995). A strategy for improving patient satisfaction by the intensive training of residents in psychosocial medicine: A controlled, randomized study. Academic Medicine, 70, 729-732.

Stewart, M. (1984). What is a successful doctor-patient interview?: A study of interactions and outcomes. Social Science \& Medicine, 19(2), 167-175.

Stewart, M. (2001). Towards a global definition of patient-centred care: The patient should be the judge of patient centred care. British Medical Journal, 24322(7284), 444-445.

Stewart, M. (2005). Reflections on the doctor-patient relationship: From evidence and experience. The British Journal of General Practice, 1:55(519), 793-801.

Wadensjö, C. (1998). Interpreting as interaction. London: Longman.

Weiss, R., \& Stuker, R. (1999). Wenn Patientinnen und Behandelnde nicht dieselbe Sprache sprechen ...: Konzepte zur Übersetzungspraxis. Sozial- und Präventivmedizin, 44, 257-263. 
1 The term "mediating agent(s)"/"MA(s)" is used here to encompass both certified interpreters and certified cultural mediators. In this paper no distinction is made between the two professional categories.

2 Both Bellack et al in Coulthard (1977, p. 97) and Goffman in Manning (1992, pp. 168169) argue that interaction consists of moves. Although Bellack et al in Coulthard (1977) distinguish among four types of moves that are to be found in interaction and define each of them by explaining the purpose each of them serves, Goffman in Manning (1992) treats the term "move" as a rather broad concept. He perceives moves as units of discourse that encompass the messages that discourse participants want to convey to each other, as well as respect for the other (ritual respect) and for the self (face-work). Moves are subject to communicative constraints, that is the requirements that speakers must meet in order for their moves to be understood. Moves can also consist of framing instructions, in other words instructions about the message that assist discourse participants with the interpretation of the move. Goffman does not elaborate on the communicative constraints; however, he seems to encompass -among other things- the discourse participants' ability to recognise the type of moves the other discourse participants engage in -structuring, soliciting, responding, reacting moves, as suggested by Bellack et al in Coulthard (1977, p. 97) - and proceed with the initiation of their subsequent move.

3 The following transcription conventions (adapted from Silverman 1993) are used in the excerpts:

(.) Short pause, probably no more than one-tenth of a second

(.4) Numbers in parentheses indicate elapsed time in silence in tenths of a second.

(bold) Information added by the transcriber

:: $\quad$ Prolongation of the immediately prior sound. The length of the row of colons indicates the length of the prolongation

( ) Inaudible

? Rising intonation as in a question

[ The speaker's talk is overlapped by another's talk

(( )) Double parentheses contain author's descriptions rather than transcriptions.

The following conventions (including the multimodal annotation) have been introduced by me:

D Doctor

P Patient

MA Mediating agent

PC Computer screen

Floor The floor of the room in which the interaction takes place. (e.g. MA $\varangle$ floor $=$ the mediating agent directs his or her gaze to the floor of the room instead of establishing eye contact with a participant he or she addresses.) 
Multimodal annotation:

$4 \quad$ Gaze (e.g. P $4 \mathrm{MA}=$ the patient looks at the mediating agent.)

The following convention has been used in compliance with the journal's general transcription requirements.

$=[\ldots] \quad$ Translation into English

4 The linguistic quality of the utterance in Turkish (turn 3) is relatively poor. The translation into English is accurate. Yet for reasons of clarity it is not as close to the source text as in the other turns of the same excerpt.

5 The MA in excerpts 2 and 3 adopts a very informal way of addressing the patient in Turkish. On the other hand, the doctor uses the formal " $u$ " (instead of the informal "je", both meaning "you" in English) marking a rather formal way of addressing the patient, which, however, is the norm for doctor-patient interactions in Dutch. It could be argued that the MA's switch into an informal way of addressing the patient could possibly create a closer doctor-patient relationship thus promoting the concept of patient-centredness. It should be noted, however, that such an informal way of addressing a patient is neither common nor expected in doctor-patient interaction in Turkish. The investigation of the MA's motives for adopting such an informal way of addressing the patient would require further explorations that would exceed the scope of the present paper. 